indicated by the assay of expressed sap. To explain this difference they have postulated the existence of a 'free' antibiotic fraction, which is obtained in water extracts or in expressed sap, and a 'bound' fraction which can be recovered from the leaf only by using suitable organic solvents.

\section{L. Herrick}

The whole of a recent issue of the Transactions of the American Philosophical Society is devoted to an account of the astonishing life of the famous American naturalist and psychobiologist, Clarence Luther Herrick (45, Part 1; 1955). The author is his younger brother, Prof. C. J. Herrick, who writes with great pride and affection of his brother's career when holding chairs at Denison University and the Universities of Cincinnati and Chicago, his posts as United States deputy mineral surveyor and president of the University of New Mexico, and manager of the Cat Mountain Mine in New Mexico which soon became bankrupt. All this was crowded into a life of forty-six years, the last eleven of which consisted of a struggle against pulmonary tuberculosis. His brother describes him as a precocious genius "whose pioneering was in areas of remarkable diversity-in natural history surveys, in geology and paleontology, in general biology and ecology, in comparative neurology and psychology, in rare proficiency as an inspiring teacher and educational administrator, in the rejuvenation and successful reorganization of a great university, in naturalistic philosophy, and in the founding of two great scientific journals".

\section{Abstracts of New Zealand Scientific Papers}

LAST year a new feature was started in the New Zealand Science Review, the official journal of the New Zealand Association of Scientists, whereby abstracts were prepared of scientific papers published in New Zealand since September 1, 1953, and, where possible, of papers published in Britain or North America which were based on work in New Zealand. By the end of the year, 502 such abstracts, covering the period up to October 30 , 1954, had been printed, and in the November-December number of the Review (12, Nos. 11-12 ; 1954) are to be found author and subject indexes for all these abstracts; the subject index is particularly full and contains nearly two thousand entries. The abstracts are arranged under subject headings, and biological and agricultural subjects, as befits a country like New Zealand, greatly predominate, though entries under physical and technological subjects, etc., are to be found. It should be borne in mind, however, as a preparatory note to the subject index explains, that very little of the work in physics, chemistry or mathematics that is done in New Zealand is published in that country, and the compilers of the abstracts are fully aware that they have not covered extensively overseas journals. The onus of directing attention to their work must always rest on the authors of papers themselves.

\section{Ramsay Memorial Fellowships for 1955-56}

RAMSAY Memorial fellowships for research in chemistry have been awarded for $1955-56$ to the following: B. R. Hammond and E. Haslam, general British fellowships at the University of Cambridge; H. Inokuchi, a Japanese fellowship at the University of Nottingham; Dr. R. V. Jordana, Dr. A. Esteve and Dr. Garcia-Moliner, Spanish fellowships at the University of Cambridge; and T. Cohen, a United States fellowship at the University of Glasgow. The following fellowships have been renewed: Dr. J. A. Davies, Canadian fellowship at the University of Leeds; Dr. L. H. Ruiter, Netherlands fellowship at the University of Bristol ; and Dr. C. Alfonso, Spanish fellowship at the University of Birmingham.

\section{Polish Medal Awards for Scientific Work}

THE following medal awards have recently been made in Poland. Biological Sciences : Prof. J. Dembowski, for general scientific work; Prof. E. Mikulaszek, for his work entitled "Immunologically Active Polysaccharoses". Mathematical and Physical Sciences: Prof. K. Borsuk, for distinguished work in topology ; Prof. L. Infeld, for outstanding achievements in theoretical physies and, in particular, for work on the theory of gravitation and non-linear electrodynamics; Prof. S. Pawłowski, for the discovery of sulphur deposits of great economic im. portance; Prof. J. Samsonowicz, for research into depth structures of the Polish Plain.

\section{Announcements}

WE regret to announce the following deaths.Prof. R. W. Wood, For.Mem.R.S., research professor of experimental physics in Johns Hopkins University, on August 11, aged eighty-seven ; Prof. J. B. Sumner, recently professor of biochemistry and director of the Enzyme Research Laboratory in Cornell University in 1946, on August 12, aged sixty-seven.

Mr. Sidney JoHn Worsuey, principal of the College of Estate Management, Kensington, has been appointed by the Secretary of State for the Colonies to be secretary of the Inter-University Council for Higher Education Overseas and of the Colonial University Grants Advisory Committee. Mr. Worsley succeeds Dr. Walter Adams, who has been appointed director of planning and principal-designate of the University College of Rhodesia and Nyasaland (see Nature, January 29, p. 193).

THE ninth General Assembly of the International Astronomical Union will be held in Dublin during August 29-September 5.

Dr. N. B. Chapman, senior lecturer in organic chemistry in the University of Southampton, has been appointed a reader in respect of that post.

THE College of Physicians of Philadelphia has awarded the Alvarenga Prize for 1955 to Dr. C. H. Rammelkamp for his outstanding work in the field of streptococcic infections, particularly in relation to rheumatic fever and nephritis.

THE following appointments in the University of London have been announced : Dr. Roger Warwick, lecturer in anatomy in the University of Manchester, to the University chair of anatomy tenable at Guy's Hospital Medical School. Dr. R. H. Gorrill, senior lecturer in bacteriology at St. Mary's Hospital Medical School, to the University readership in bacteriology tenable at Guy's Hospital Medical School.

The ninth annual conference of the Stress Analysis Group of the Institute of Physics will be held during September 28-30 in the Stephenson Hall, University of Sheffield, and will deal with applications of stress analysis. Enrolment forms and further information can be obtained from the Secretary of the Institute, 47 Belgrave Square, London, S.W.1. 